\title{
City as a System Supported by Artificial Intelligence
}

\author{
Anna Bazan-Krzywoszańska ${ }^{1}$,, Robert Lach $^{2}$, Maria Mrówczyńska ${ }^{1}$ \\ ${ }^{1}$ Faculty of Civil Engineering Architecture and Environmental Engineering, University of Zielona Góra, Zielona Góra, Poland \\ ${ }^{2}$ Spatial Data System Sp. z o.o., Gliwice, Poland
}

Email address:

A.Bazan $a$ aiu.uz.zgora.pl (A. Bazan-Krzywoszańska), robertlach00@gmail.com(R. Lach),

M.Mrowczynska@ib.uz.zgora.pl (M. Mrówczyńska)

${ }^{*}$ Corresponding author

\section{To cite this article:}

Anna Bazan-Krzywoszańska, Robert Lach, Maria Mrówczyńska. City as a System Supported by Artificial Intelligence. Urban and Regional Planning. Special Issue: Management of the City - A Multi-Branch Task. Vol. 5, No. 2, 2020, pp. 32-39. doi: 10.11648/j.urp.20200502.11

Received: February 25, 2020; Accepted: April 7, 2020; Published: April 28, 2020

\begin{abstract}
The primary objective of urban policy is to strengthen the capacity of cities to develop in such a way as to create an efficient, compact, sustainable and coherent structure, and thus to be strong and competitive. The potential associated with reducing urban flows, combined with effective management and use of natural resources, depends on sustainable development, but also on factors such as: compactness of form, morphology and urban structure of settlement units, among which cities become a space with great potential for saving natural resources, e.g. energy. The new approach towards thinking about city and planning its space entails consequences. The study of cities' functionality is more and more involved with the process of integrating often dispersed, interdisciplinary databases. They provide information about the status and operation of a city system, based on qualitative and quantitative data. Earlier access to broad data sets was quite limited, but with the liberalization of access to satellite imagery data in Europe, and with more frequent operational functioning of several constellation of various image resolutions, practically each city on Earth can start to apply spatio-temporal monitoring of growth of urban organisms. It is already possible to monitor urban change with medium, high and very high resolution imagery at the entire Earth surface. These monitoring techniques procedures involve continuous observation and supervision. These types of activities allow to monitor the implementation of spatial policy processes, with regard to the set short- and long-term objectives. They can also help to initiate feedback processes related to possible adjustment of targets, thus - enriching decision makers with a broader, or better decision support, improving decision-making process with the use of big geospatial data. Space planning took on a new significance, since taking into consideration shaping the living conditions in the context of that process's implications. Given the above, there is a need to develop tools to support conscious and effective implementation of spatial policy objectives. The complexity of processes occurring in space, as well as the willingness to understand and describe them, results in the development of new research techniques. The tools based on artificial intelligence are very helpful. The process of digital transformation of society and economy with the participation of algorithms is great developmental challenges of the XXI century. Public services in this system must be deeply rich with data. For this reason, in recent years, data has become one of the main or even the most important production factor. The acquisition, collection, analysis, processing and use of data and the continuous development of algorithms is becoming a fundamental competence of countries and cities.
\end{abstract}

Keywords: City Space Management, GIS, SDI, 3D/4D City Models, CityGML, Big Data

\section{Introduction}

Efficient city management involves the supervision instruments and decision-making bodies. This requires facing the challenges of a large number of actors involved in the decision-making process, with the fragmentation of their competences and responsibilities, with the development of technologies, or with the methods of financing projects. New management ways require cooperation of public and private entities, local communities and institutions involved in the management of resources. Effective city development policy takes into account the entire system and its interactions, and the principles are oriented in short and long term targets [1].

Through the development of computing power, the growing 
number of sources of real-time data acquisition (platforms and digital assisted management systems), and above all through Artifcial Intelligence (AI), we have achieved an unprecedented development of the ability to manage complex issues that exceed human cognitive capabilities or human mind performance. They allow you simulate, monitor, forecast processes and consequently manage urban systems [2]. AI systems are based on the way human neurons work (Figure 1, Figure 2).

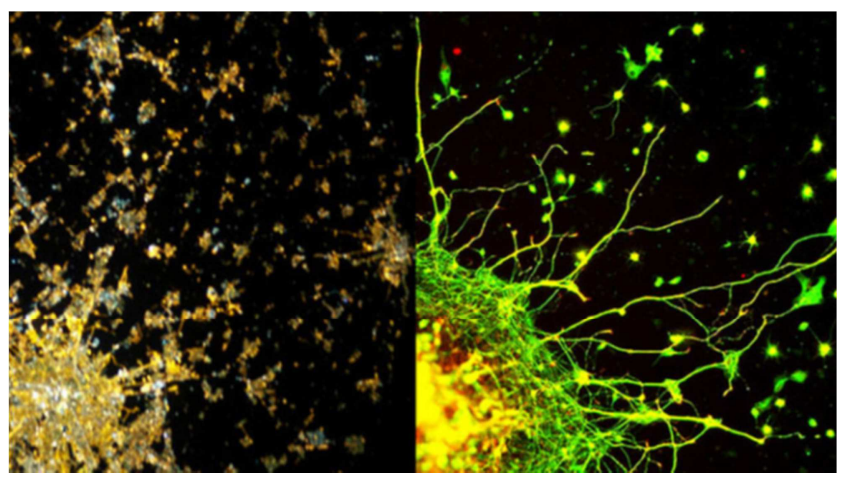

Figure 1. Comparison between metropolitan city observed in the night from International Space Station (left) and human neuron (right) [3, 4].
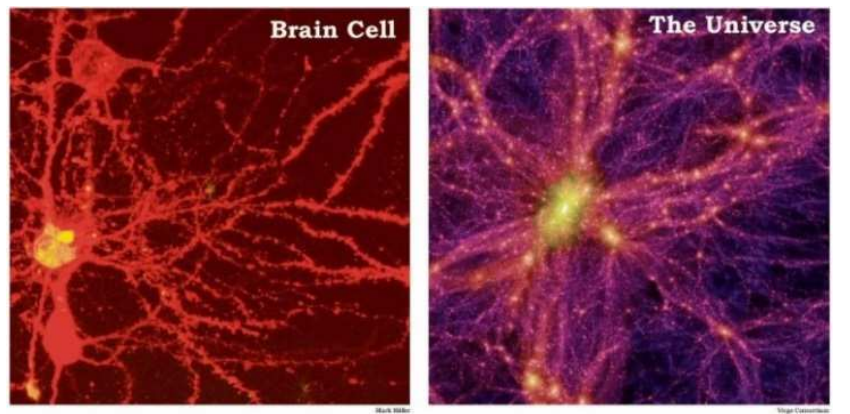

Figure 2. Comparison between human brain cells (left) and the Universe galaxies (right) [5].

\subsection{Decision-making Processes}

The essence of decision making is the awareness of the possible choices and, simultaneously, the results of those choices. It must therefore be assumed that decision-making processes are the main element of management, which determines the efficiency of the related system. The decision-making process (decision) should be effective, efficient and taken in an appropriate timeframe, considering existing or possible relationships and links between the elements. This indicates that decisions cannot be made purely on the basis of intuition, but must be supported by, for example, scientific methods and actions used in decision-making processes. In this sense, the decision-making process is the action of solving a problem, communicating this solution as normative information (the right decision) and consistently enforcing its objectives. Therefore, decisions should be the result of a rational problem solving, reliable assessment of the situation resulting from the collected information, logic, experience and intuition [6], it means that they are subject to optimization.
One of the tools supporting decision making (concerning urbanized space) is the visualization of knowledge, previously provided by legal language and two-dimensional drawing, using the potential of three-dimensional digital space modeling. It affects the effectiveness of actions, by linking databases (knowledge) and standardizing them [7]. Visualization, in its considered nature, is a tool helpful in a more effective perception of analyses, improved experience and shorter recipient response time.

With the current state of knowledge and challenges of the modern economy, considering the complexity of the problems that require a decision to be made, techniques supporting the indication and targeting of a solution become a helpful tool. A useful role in making such choices and making decisions in a rational, multi-criteria way ${ }^{1}$, among other things, is played by Multi Cryteria Decision Analysis (MCDA), Multi Cryteria Decision-Making (MCDM) and Multidimensional Comparative Analysis (MCA) [8]. Thanks to these methods, space management problems can be assessed not only through measurable economic criteria, but also through operational methods, including effective tools.

Many scientific disciplines are involved in describing the decision-making process, including: statistics [9], sociology, management, computer science, cognitive science ${ }^{2}$. [Matlin, 2005] or psychology [10] Each of the sciences considers the decision-making process according to its own specific aspects, but all of them find their origin in the processes taking place in the brain. Following this path, decision-making issues can be described with mathematics and reality models. The method of dealing with these cases is based on assumptions having their basis in economics and related disciplines, including, among others, statistics and decision optimisation studies. Within the latter, the main actors in the process become decision-makers, whose task is, by means of a set of adopted evaluation criteria, to make a decision, bearing in mind often conflicting or mutually exclusive objectives ${ }^{3}$ [8].

\subsection{Space Management}

Management, as the conscious shaping of the relationship between the elements of a system, is understood as the coordination of collective efforts to achieve a given objective. Systems separated from the environment, internally structured with separated and defined elements, are characterized by internal and external connections or links (with the environment), having functional goals, human and technical resources necessary for their implementation.

Contemporary concepts of economy development indicate management as the most important factor of this development, understood as activity related to decision making and control of resources, processes and data sets in order to achieve optimal

$1 \mathrm{MCDM} / \mathrm{MCDA}$ problems can be divided into Multi-attribute decision making (MADM) and Multi-purpose decision making (MODM)

2A field of science dealing in particular with the analysis of the functioning of the senses and the brain

3 A multi-criteria decision problem, characterised by the subjectivity of problem definition, objectives, selection of criteria and ultimately assessment of the impact of the decision. 
results, with the most efficient and economical activities and social acceptance. The ability to manage is related to the way of decision making. Modern management must be characterized by the ability to find a balance between the variability and unpredictability of the market and preserving the value of the surrounding space, strongly dependent on the economic situation as well as the geopolitical context. Considering that the space users have the right to co-create a vision of its development, it means that in the process of management, citizens along with decision-makers are a group of participants influencing the process [11]. A necessary condition for effective space management, through spatial planning, is knowledge of phenomena and processes taking place in the space. This should be done by a monitoring system based on a structured conceptual sphere, unified in terms of acquisition, analysis and presentation of the database, as well as in terms of applied indicators and parameters [12].

\section{A City Concept}

Cities require constant access to natural resources for free functioning and development. The urban form and structure of cities shapes the way of living, moving and functioning of their inhabitants [13]. As the population grows, the demand for natural resources, defined as raw materials such as fuels, minerals and metals, food, soil, water, air, biomass, ecosystems [14] increases. Uncontrolled urban development can contribute to the shortage of natural resources and the degradation of ecosystems.

Cities are becoming a space with huge savings potential in terms of natural resources and energy. With more than $50 \%$ of the world's population and, in the case of Europe, $72 \%$ of the total EU population living in urban areas, the problem of minimising resource use, reducing waste and greenhouse gas emissions is still relevant and cities are becoming the most effective place to make savings. Cities are the most efficient tool - engine for managing change and thus reducing resource use by adopting an integrated approach to development planning [13].

The potential to reduce urban flows, combined with efficient management and use of natural resources, depends on sustainable urban development, but also on factors such as compactness of form, morphology and urban structure. In most cases, these factors indicate the current needs of settlement units, e.g. through indicators related to determination of the buildings and roads' technical condition, as well as quality and manner of service provision. Monitoring, local action programs or integrated development strategies influence the city management method defined by managing authorities, local governments and spatial planners. Optimization of a city's functioning cycle begins with an analysis of its functioning and the condition of a building, housing estate, district, region and finally the whole structure on a local or regional scale. The best results are achieved by managing individual resources on their optimal scales [15].

Efficient city management involves the supervision instruments and decision-making bodies. This requires facing the challenges related to the fragmentation of responsibilities and the way of decision-making of numerous entities, meeting technical and technological, but also financial challenges, and above all, the cooperation of public and private entities, the local community and individuals who contribute to the management of commune resources through decisions and practice at different levels of decision-making, within the framework of the city's functioning system.

Management at the level of cities, in relation to their development policies and the efficient use of natural resources, including local factors, has a great importance (city system management, spatial planning, urban planning). However, without global trends, guidelines at the country level, also in political terms, it is difficult to expect significant results.

\section{3D and 4D Models of Cities}

Changing the way of thinking about space from two-dimensional (2D) to three-dimensional (3D) and four-dimensional (3D+ time) has brought many benefits in the way we understand various urban issues. Where as there were a lot of successful efforts connected to $3 \mathrm{D}$ visualization of cities in 3D, already in the 90-ties, only contemporary, standardized 3D/4D models allow for the execution of complex analytical tasks. The virtual models allow, among other things, to simulate complex analytical tasks, used to manage urban infrastructure or support decision-making processes. Standard CityGML, as an open model for virtual data storage and exchange, was approved by the Open Geospatial Consortium (OGC) ${ }^{4}$ in its first version in 2008 (Figure 3). Virtual, three-dimensional city models currently developed in the CityGML standard (Figure 4) and published on the Internet are a consequence of the development of knowledge on the subject, through research and work carried out, among others, by T. H. Kolbe and the team [16, 17], who is considered the creator of the standard. The pioneer in analysing the possibility of using the system in Europe was the Netherlands, which, on the basis of the work carried out by the team led by J. Stoter [18], approved the government standard for 3D data exchange (IM GEO standard).

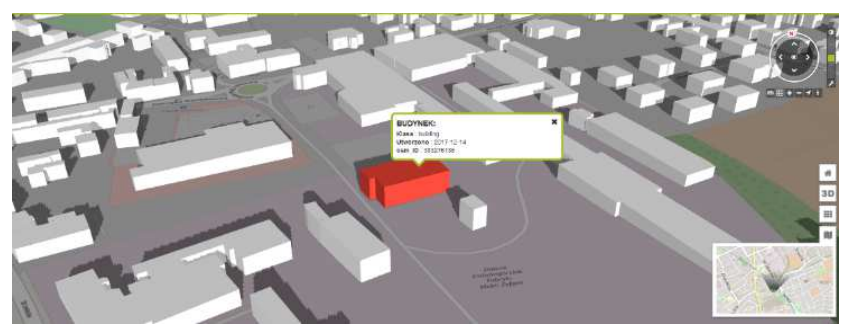

Figure 3. The geometry of an example building with the basic descriptive parameter, created in CityGML standard, level of details (LOD1), viewed in virtualcitySUITE, 2018.

$4 \mathrm{OGC}$ is an international non-profit organization that brings together government agencies, science centers and industry representatives. Its main task is to develop knowledge and implement open standards of data and geospatial services for the purposes of widespread, public use. 


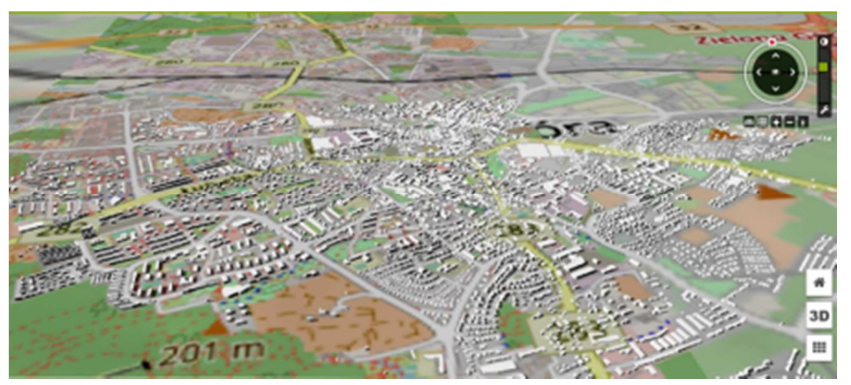

Figure 4. Model of the City of Zielona Góra, created in CityGML standard, level of details (LOD1), viewed in virtualcitySUITE, 2018.

Europe is today a continent with the highest density of created $3 \mathrm{D}$ city models, in comparison to other continents. CityGML standard started to be used [19], initially within city administrations of biggest metropolitan cities of Western and Northern Europe. (Dresden, Berlin, Hamburg, Munich, Köln, Vienna) and appropriately: Helsinki, Stockholm, Oslo. This bottom-up development trend, chosen by the cities by themselves - is coming from the ease of use of standardized language for 3D data exchange, compared with earlier possibilities of other, existing 3D data formats (Figure 5).

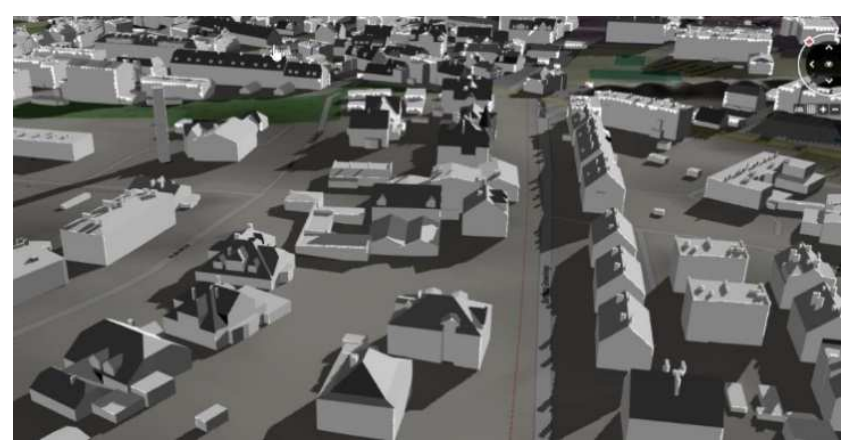

Figure 5. Resulting model with generated buildigns of the City Centre of Zielona Góra, in CityGML standard, level of details (LOD2), viewed in virtualcitySUITE package, 2018.

Since CityGML is also an open and modular standard, its extension is relatively easy to the other application fields/domains. The most interesting to authors are already available CityGML Application Domain Extensions (ADE) of the $4^{\text {th }}$ dimension - ADE Dynamizer, ADE Energy, cadastral Land Administration Domain Model (LADM) and some others from 44 extensions being discussed in literature [20].

ADE Dynamizer - extension module mentioned above, created by scientists from Munich University allows for the same priority treatment of all the entities of the time series data and to store them in the structured of Relational Data Bases [21]. Extended aplications give the ability of visualization of complex data sets, be it in micro- or macro scale of time. Example of micro-scale might be time-series of data related to 24 hours cycle of electric energy consumption of a single family building or macro-scale example of overlapping of the orthophotomaps of the same city, let's say, in 20 years perspective, with 2 years repetition cycle. Dynamizer might allow to compare and visualize each development phase of the growth of city organisms, monitored every 2 years, or with any other repetition cycle. Then the automatic or semiautomatic detection change might be applied to 2 neighboring (in time) orthophotmaps, providing the ability to monitor exact changes and to store them and retrieve with the usage RDBMS tools.

ADE Energy - extension module allows for construction of full energy model of the cities, what has very significant meaning while researching the areas of potential savings of energy, used by the cities, optimization of energy needs of the cities, or tailoring the renewable energy sources into energetic balance of cities, regions, and states [22].

Presentation of research results, with a tool such as the three-dimensional model of the city space, enables the integration of data sets from various public registers and visualization of the scope of analyses in an easy-to-read and understandable way. Digital model is a useful tool used for the analysis and decision-making support in the issues of land use, where it is possible to visualize the dependence and impact of the examined elements, e.g. on each other [23].

\section{Spatial Data Infrastructure and Artificial Intelligence}

The research shows the benefits of integrating databases within the applied Geographic Information System (GIS) techniques into the issues related to spatial planning and decision making process. GIS builds datasets and algorithms along with processing and sharing procedures. However, it has limited possibilities to process data on opinions and preferences, which is the subject of public participation for the implementation of spatial policy. Land or Geographic Information Systems in their early phases did not have ability of wide usage of dispersed data bases and usually had a determined access, limited to just one institution in one or several buildings, or to the network of connected LAN terminals. Significant turning point between GIS and SDI époques was elaboration and wider access to SOA (Service Oriented Architecture) as a result of creation and gradual development of Internet and the process of standardization of network services. This has led to practically unlimited possibilities of execution of analyses, independently from the physical location of the existing digital data sources. It has also opened the way to systemic association of various and sometimes very distant, data, in both thematically and physically formed results.

Combining GIS with the method of multi-criteria analysis [24] may be a way to increase the capabilities of GIS systems in reference to the identified problem. The main elements of this type of models may be: decision-makers ${ }^{5}$, criteria $^{6}$ and decisions or their alternatives ${ }^{7}$. The combination of GIS with

\footnotetext{
5 The decision-maker in a multi-criteria analysis is the person or group of people responsible for making the decision; Whether we are dealing with one or more decision-makers in the process is determined only by the consistency of the objectives and preferences of those concerned

6 Criteria are the basis for decision making, they are used to assess the possibility of setting alternative decisions; the criterion is complete and measurable, the set of criteria is closed and their number should be as small as possible.

7 Spatial decision-making alternatives concern the choice of action and location;
} 
multi-criteria analysis enhances the model's ability to process and analyze spatial data in conjunction with information on social preferences. It can be used in space decision-making processes [25]. The idea of Classification and Regression Tress (C\&RT) gives the possibility to build models that are helpful in the analysis of systems in which the variable is a quantitative feature (regression) as well as a qualitative dependent variable (classification). The advantage of this modeling is the ease of interpretation of the results. One of the more interesting mathematical models, created by human, is an artificial intelligence model describing how the human brain works. For this purpose, various types of artificial neural networks are used. Their most interesting feature is the ability to process data/information in a parallel way, while being able to learn. They are useful in the analysis of issues where input data is incomplete and results are approximate [26]. Modeling using Fuzzy Cognitive Map (FCM) [27] is a very interesting study that provides an opportunity to combine qualitative and quantitative approaches through event scenarios, using the ability to tell how system elements interact with each other.

Artificial Neural networks (ANN) have found broad application areas for resolution of interdisciplinary problems. Properties of the networks allow for its use for resolution of such a tasks like: classification and automatic data recognition, its analysis and association, signals filtration, prediction and optimization of decision -making process, among the others.

ANN are currently being more frequently used for supporting of management of urban areas as well as in relation to individual construction objects. New methods of modeling of city landscape allow for better description of cities and their societies [28]. Merging of classical management methods and city modelling with artificial intelligence allows for creation of models, which enable for control and simulation of living environment, which might be the best for its citizens [29].

Independently, among the models using artificial intelligence, the so-called hybrid integration models [30] have proved to be helpful in describing reality and supporting decisions including describing the phenomenon of spatial development of cities [29, 31]. Hybrid models "are characterized by generating a combination of continuous and discrete signals subject to interaction with other signals or environments" [29]. This means that these models are a combination of discrete and continuous models. Discrete models can represent phenomena with low to medium levels of abstraction and a large number of details. Continuous models allow to simulate phenomena with low and medium levels of details (Figure 6).

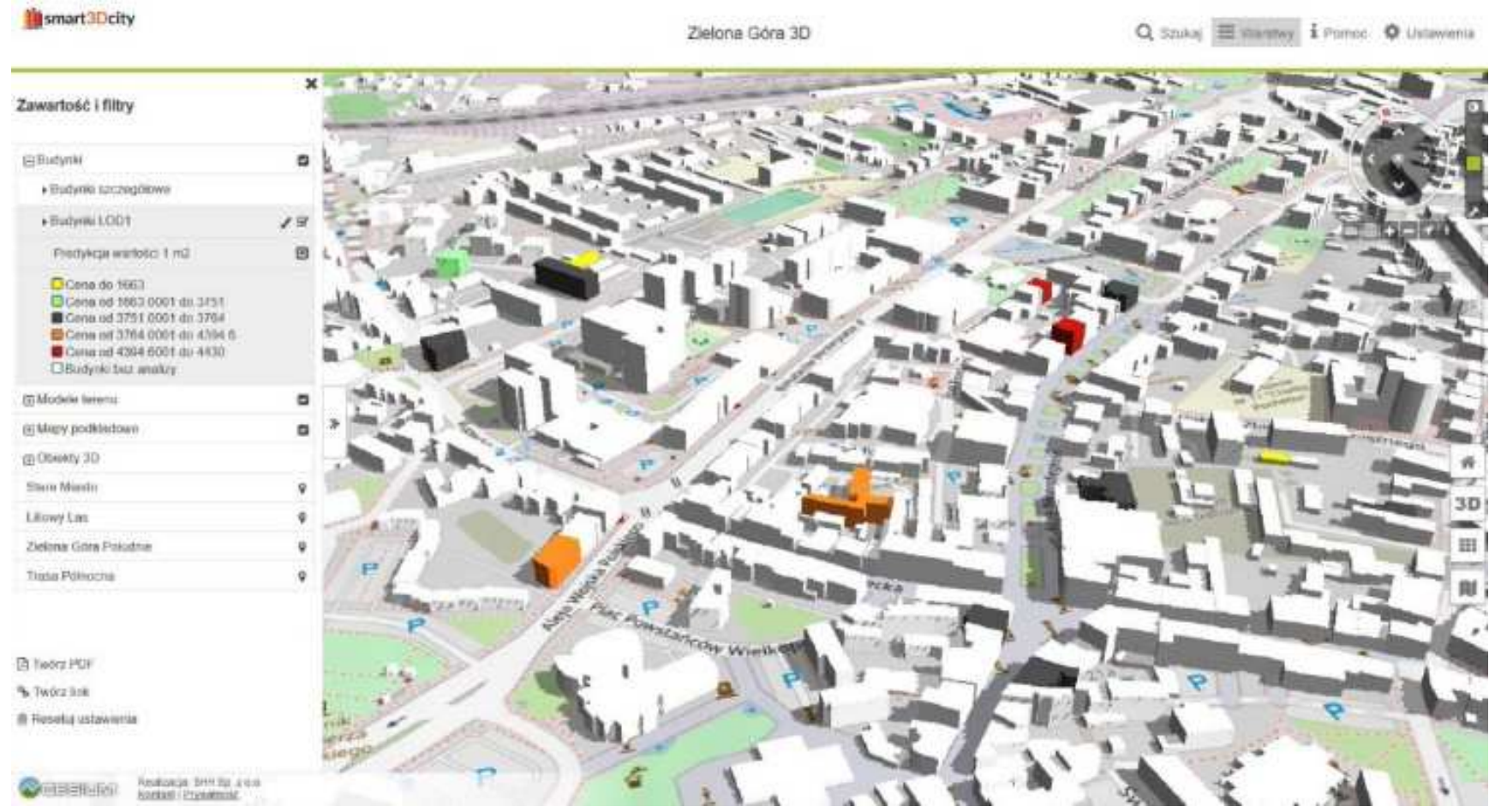

Figure 6. Resulting model of generation of buildings of the City of Zielona Góra in CityGML LOD1, prezented in virtualcitySUITE software, with the result of deep learning of neural networks, in the area of prediction of price of $1 \mathrm{~m}^{2}$ of real estate.

Persistent Change Monitoring (PCM) methodology allows to eliminate non-important changes, and to monitor factual changes on the Earth surface, what is possible due to usage of time series of very high resolution satellites, which collected systematically imagery data from 1999 year. Usage of Landsat and Sentinel data is now possible for the entire Earth. Three images show the process of development of the Port of Chennai in India, in time frame from 1998 (Figure 7) to 2018 (Figure 8) with application of PCM method (Figure 9) [32, 33]. 


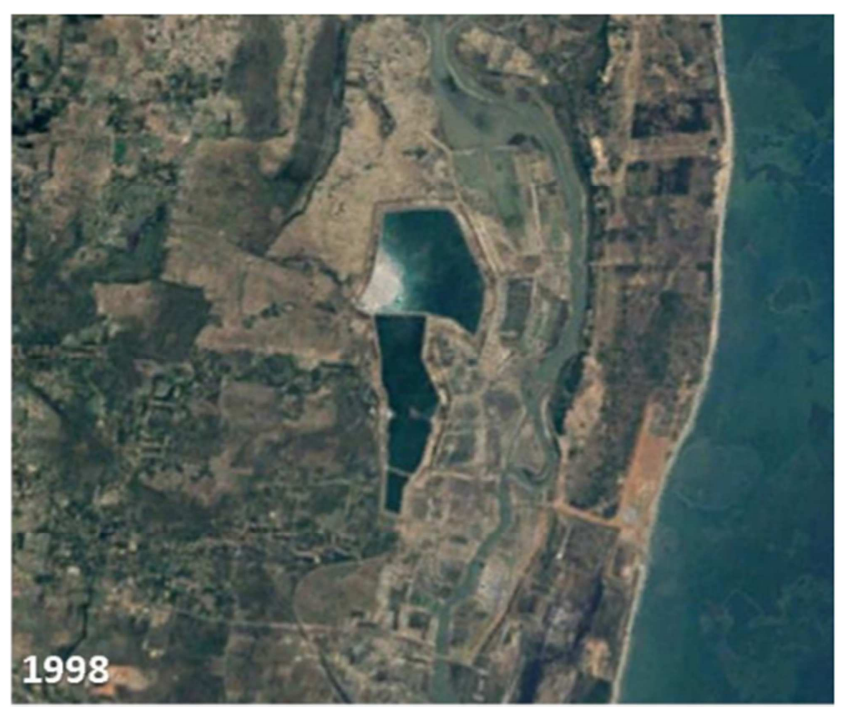

Figure 7. Image of Chennai India, 1998.

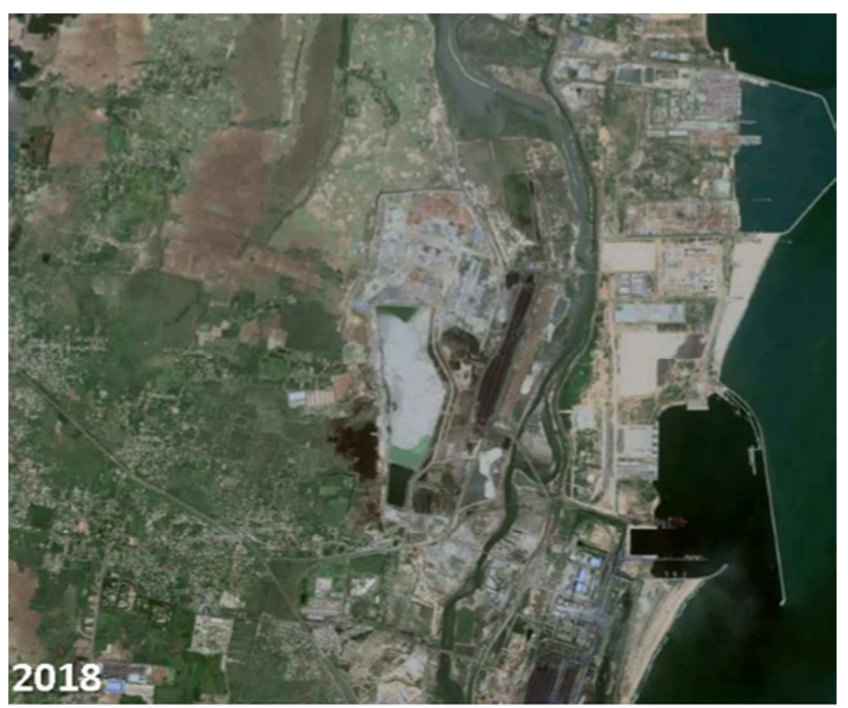

Figure 8. Image of Chennai, India, 2018.
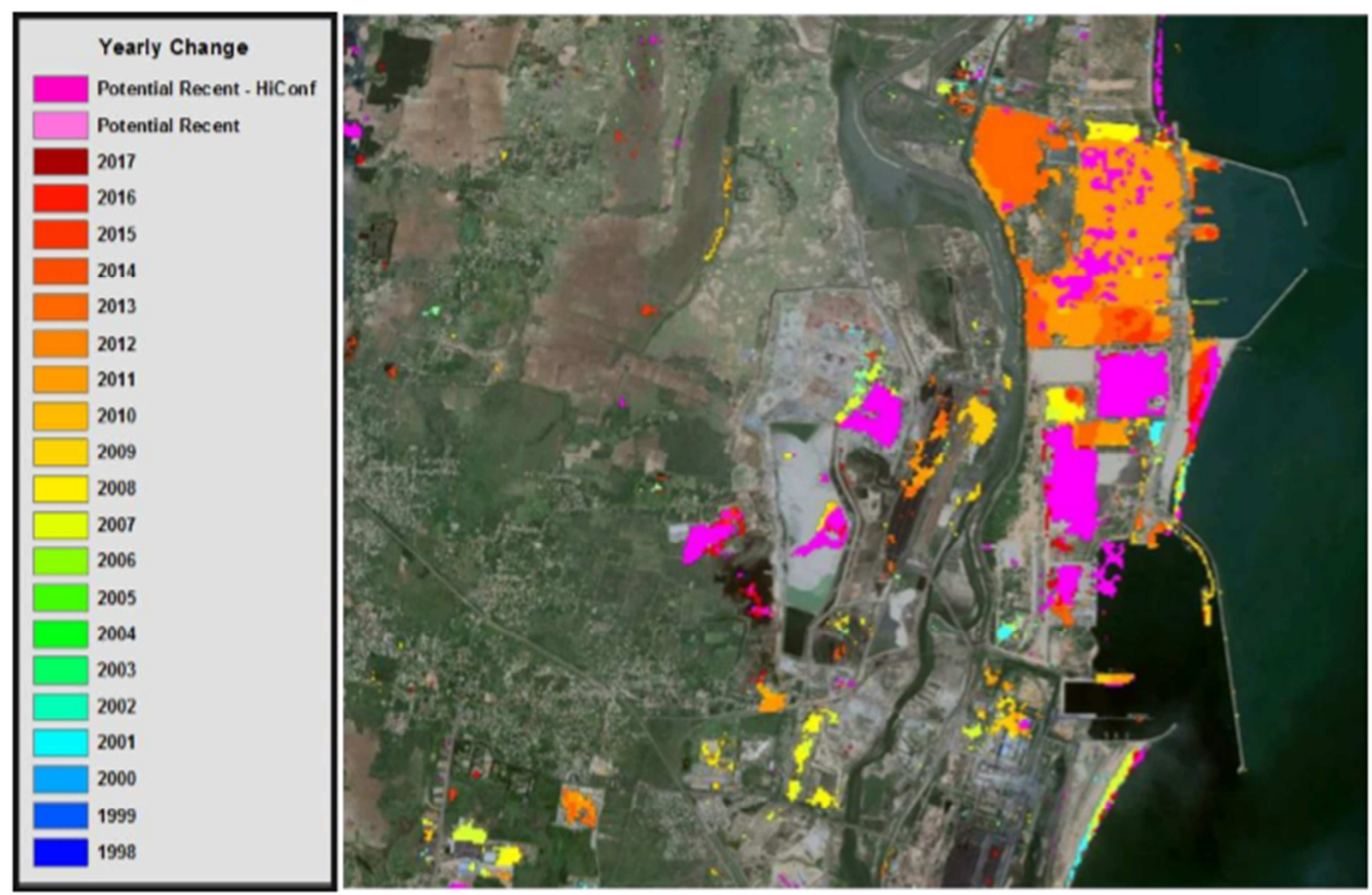

Figure 9. Process of development of Chennai Port 1998-2018.

\section{Conclusions}

Currently, a city spatial planning is challenged mostly by the need to designate the main directions of the development. The implementation of the aforementioned requires system support, in which quantitative planning ought to be combined with quality. This approach towards thinking about a city and planning its space is associated with the consequences of creating a logical and effective system of spatial planning, which is one form of response to the needs of citizens. Cities are expected to be functional, above all. The study of functionality should involve a process of integration of databases, which often are dispersed or interdisciplinary. They provide information about the status and the way the system of a city works, on the basis of various data qualitative and quantitative sets.

One of the tools to create spatial policy are planning documents, which at the local-municipal level, that is essential for the State administration include local zoning plans. Local zoning plans, inter alia through the legally required records on urban indicators and parameters of shaping development, carries out objectives of spatial policy. 
Application of artificial intelligence for supporting decision-making processes, ie. supporting city management through systematization and data sharing allows for delivery of theoretical information - related for specific elements of the city and for indication for its development. Artificial intelligence applied in the areas of prediction, classification and image recognition allows for underlining characteristic features for inteligent cities and propagates concepts of sustainable development, focused on low-emission technologies. Presented issues form a theoretical basis, allowing for construction of concept, optimal for life of its dwellers, being resonably manages and serivced.

\section{Acknowledgements}

Stanisław Biernat - SHH Sp. z o.o. Wrocław, Poland Andy Stephenson, Alberto Lopez - MAXAR Technologies Ltd.

\section{References}

[1] Bazan-Krzywoszańska, GIS technology as a tool for protecting landscape and cultural values in spatial planning, Structure, 2018, p. 129-137.

[2] Artificial Intelligence Development Policy in Poland, Ministry of Digital Affairs, https://www.gov.pl/web/digitalization, typescript.

[3] https://www.cnet.com/pictures/iss-night-shots/10/

[4] Leitch, Modified CRISPR Can Manipulate Gene Activity in Neurons, 2019 , https://www.labroots.com/trending/genetics-and-genomics/15 458/modified-crispr-manipulate-gene-activity-neurons

[5] M. Gosh, A Brain Cell and The Universe, 2008, https://walkingthefenceline.wordpress.com/2008/05/15/a-brai n-cell-and-the-universe/

[6] J. Penc, Decyzje w zarząadzaniu, Wydawnictwo Profesjonalnej Szkoły Biznesu, Kraków 1995.

[7] P. Ozimek, J. Tarko, P. Łabędź, Cyfrowe modele analizy krajobrazu bazujące na cyfrowych modelach terenu systemów informacji przestrzennej, Prace Komisji Krajobrazu Kulturowego PTG, 14, Sosnowiec 2010.

[8] K. Nermend, Metody analizy wielokryterialnej i wielowymiarowej we wspomaganiu decyzji, Wydawnictwo Naukowe PWN, Warszawa 2017.

[9] J. Berger, Statistical decision theory. Foundations, concepts and methods, Springer Verlag, GmbH 1990.

[10] W. Edwards, B. Fasolo Decision Technology, Annual Review of Psychology, T. 52, 2001, p. 581-606.

[11] Mironowicz, Czynniki przestrzenne, kulturowe i społeczno-ekonomiczne w zarządzaniu rozwojuem miast, w: Zarządzanie rozwojem przestrzennym miast (red.) Lorens P., Martyniuk-Pęczek J., Miasto-Metropolia-Region, Akapit-DTP, Gdańsk, 2014, p. 120-137.

[12] P. Śleszyński, Propozycja kompleksowej koncepcji wskaźników zagospodarowania i ładu przestrzennego, w: Wskaźniki zagospodarowania i ładu przestrzennego w gminach (red.) P. Śleszyński, Biuletyn Komitet Przestrzennego Zagospodarowania Kraju, Polska Akademia Nauk, Z. 252, Warszawa, 2013, p. 176-231.

[13] Urban sustainability issues - What is a resource-efficient city? European Environment Agency Technical Report 23, 2015. https://www.eea.europa.eu/publications/resource-efficient-citi es.

[14] A resource-efficient Europe - Flagship initiative under the Europe 2020 Strategy. Communication from the Commission to the European Parliament, the Council, the European Economic and Social Committee and the Committee of the Regions (COM (2011) 21-26 January 2011).

[15] C. M. Agudelo-Vera, A. R. Mels, K. J. Keesman, H. H. H. Rijnaarts H. H. M., Resource management as a key factor for sustainable urban planning, Journal of Environmental Management, 92, 2011, p. 2295-2303.

[16] Fischer, T. H. Kolbe, F. Lang, A. B. Cremers, W. Förstner, L. Plümer, V. Steinhage, Extracting Buildings from Aerial Images Using Hierarchical Aggregation in 2D and 3D, Compuer Vision and Image Understanding, 72, 1998, p. 185-203.

[17] T. H. Kolbe, C. Negel, A. Stadler, CityGML - OGC Standard for Photogrammetry?, Photogrammetric Week, 2009, p. 265-277.

[18] J. Stoter, H. D. Ploeger, Property in 3D - registration of multiple use ofspace: current practice in Holland and the needfor a 3D cadastre, Computers, Environment and Urban Systems, 27, 2003, p. 553-570.

[19] F. Biljecki, K. Kumar, C. Nagel, CityGML Application Domain Extension (ADE): overview of developments. Open geospatial data, softw. stand. 3, 13, 2018.

[20] Giorgio, Austrian Institute of Technology, TU Delft Welcome ADE Energy 1.0, $9^{\text {th }}$ ADE Energy Workshop, SIG Group Meeting, Aachen, June $26^{\text {th }} 2018$.

[21] T. Kutzner, T. Kolbe, 38. Wissenschaftlich-Technische Jahrestagung der DGPF und PFGK18 Tagung in München Publikationen der DGPF, Band 27, 2018.

[22] P. Ozimek, A. Böhm, A. Ozimek, W. Wańkowicz, Planowanie przestrzeni o wysokich walorach krajobrazowych przy wykorzystaniu cyfrowych analiz terenu wraz $\mathrm{z}$ ocena ekonomiczna, Politechnika Krakowska, Kraków 2013.

[23] Kobryń, Wielokryterialne wspomaganie decyzji w gospodarowaniu przestrzenią, Difin SA, Warszawa 2014.

[24] J. Malczewski, J. Jaroszewicz, Podstawy analiz wielokryterialnych w systemach informacji geograficznej, Oficyna Wydawnicza Politechniki Warszawskiej, Warszawa 2018.

[25] G. Grekousis G., Artificial neural networks and deep learning in urban geography: A systematic review and meta- analysis, Computers, Environment and Urban Systems. https://doi.org/10.1016/j.compenvurbsys.2018.10.008, 2018.

[26] Kosko, Fuzzy kognitive maps, International Journal of Man-Machine Studies, 24, 1986, p. 65-75.

[27] X. Zhang, G. Xu, X. Mou, et al., A convolutional neural network for the detection of asynchronous steady state motion visual evoked potential IEEE Trans. Neural Syst. Rehabil. Eng., PP (99), 2019, p. 1. 
[28] Yan-Wen Li, Ke Cao, Establishment and application of intelligent city building information model based on BP neural network model, Computer Communications, Volume 153, 2020, Pages 382-389, ISSN 0140-3664, https://doi.org/10.1016/j.comcom.2020.02.013.

[29] P. Antsaklis, A Brief Introduction to the Theory and Applications of Hybrid Systems, Special Issue on Hybrid Systems: Theory and Applications. https://ieeexplore. ieee.org/stamp/stamp.jsp?arnumber=871299, 2000.

[30] H. Shafizadeh-Moghadam, A. Tayebi, M. Ahmadlou, M. Reza Delavar, M. Hasanlou, Integration of genetic algorithm and multiple kernel support vector regression for modeling urban growth, Computers, Environment and Urban Systems, 65, 2017, p. $28-40$.

[31] M. Beim, Modelowanie procesu suburbanizacji w aglomeracji poznańskiej, Bogucki Wydawnictwo Naukowe, Poznań 2009.

[32] A. Stephenson, A. Lopez, Persistent Change Monitoring, MAXAR PCM methodology description, 2020.

[33] M. Sudmanns, D. Tiede, H. Augustin, S. Lang, Assessing global Sentinel-2 coverage dynamics and data availability for operational Earth observation (EO) applications using the EO-Compass, International Journal of Digital Earth, 2019, DOI: 10.1080/17538947.2019.1572799. 